This is a self-archived version of an original article. This version may differ from the original in pagination and typographic details.

Author(s): Karjalainen, Noora

Title: Origins and originality : Authenticity in the media representation of Julie Fowlis

Year: 2018

Version: Accepted version (Final draft)

Copyright: @ 2018 Intellect LTD

Rights: In Copyright

Rights url: http://rightsstatements.org/page/lnC/1.0/?language=en

Please cite the original version:

Karjalainen, N. (2018). Origins and originality : Authenticity in the media representation of Julie Fowlis. Journal of European Popular Culture, 9(2), 75-91. https://doi.org/10.1386/jepc.9.2.75_1 


\title{
Origins and originality: Authenticity in the media representation of Julie Fowlis
}

Noora Karjalainen, University of Jyväskylä

\begin{abstract}
This article examines the ways in which Scottish Gaelic singer Julie Fowlis is constructed 'authentic' in the media. Two narratives that I call 'narrative of origins' and 'narrative of professionalism' construct her authenticity as a representative of the folk music scene. Fowlis represents the new Gaelic speaker, but is presented in terms of stereotypical imagery connected to Scotland, which portrays tradition as stagnant, quaint and in need of preservation. However, she is also presented as a professional artist, remaking and reinterpreting the tradition of a living culture that she represents. Thus, here authenticity ascribed on the artist is viewed as a cultural memory device, built on the interaction of individual collective levels of remembering and the process of premediation with it. The material analysed consists of printed and electronic articles, concert and album reviews, and interviews written about Fowlis. The theoretical framework is based on the discussion on the concept of authenticity and on memory studies.
\end{abstract}

\section{Keywords}

authenticity

female artists 
folk music

media representation

cultural memory

premediation

In this article I discuss the ways in which Scottish Gaelic singer Julie Fowlis is constructed as an 'authentic' folk singer in the media. I argue that this authenticity is to great extent based on descriptions of her origin and professionalism. The former consists of her place of origin, her sound (performance language, sound of the voice, signature style and the values attached to all these) and links to tradition, together forming what I call the narrative of origins (Karjalainen 2017). The latter, drawing on Fowlis's musicianship, work ethic and dedication to the craft, forms the narrative of professionalism. These two narratives are discernible in texts written by journalists, and interviews in which her own words are quoted. Through selected examples from the text data of articles, reviews and interviews this article aims to clarify how the above narratives construct a female folk singer as an authentic representative of the folk music scene. The case of Fowlis serves as an example of how authenticity becomes an important part of the representation of a female folk singer.

In the analysis I apply authenticity as discussed by Keir Keightley (2001), Allan Moore (2002), Hans Weisethaunet and Ulf Lindberg (2010), Steve Redhead and John Street (1989), Regina Bendix (1997) and Vincent J. Cheng (2004). These studies discuss the concept of authenticity mainly in rock or pop music, with occasional references to the folk collectors of the first half of the twentieth century or the artists of the Folk Revivals of the 
1960-70s or the 1990s. The contemporary folk music artists have not yet received much attention in studies on music and authenticity, even though many of them - like Julie Fowlis

- have a profound influence in the folk music scene and have also attracted the interest of mainstream music business. This article aims to fill this gap.

In addition to the above theoretical approach, this article draws on the studies by Astrid Erll (2009, 2011) and Emily Keightley and Michael Pickering (2012) with cultural memory and premediation as the most central concepts. According to them, individuals remember as members of various social groups (Keightley and Pickering 2012: 94, 103), and therefore construct and reconstruct their understanding of the world and phenomena via premediation, meaning the use of media that already exist in cultural memory (Erll 2009: 111; see also Keightley and Pickering 2012: 198-99). I claim that ascribing authenticity in this context is a memory device and a negotiation between the individual and collective levels of cultural memory (Erll 2011: 98). This approach plays a significant role in explaining the uniformity of the narratives of Fowlis's authenticity throughout the analysed media text data.

\section{Research material and focus}

The material of this article consists of both printed and electronic articles, concert and album reviews and interviews that were published in 2007-15. Altogether 28 texts were studied for this article and the table below displays the source and text types:

\begin{tabular}{|l|l|l|l|}
\hline Source/text type & Article & Review & Interview \\
\hline Newspaper & Bothell Reporter & The Boston Phoenix & The Boston Globe \\
& Fairfax County Times & The Guardian & The Sun \\
& Pittsburgh City Paper & The Telegraph (2) & \\
& Scotland Herald (3) & & \\
& The Guardian & & \\
\hline
\end{tabular}




\begin{tabular}{|l|l|l|l|}
\hline & $\begin{array}{l}\text { The Sentinel } \\
\text { The Vancouver Sun }\end{array}$ & & \\
\hline Music magazine & $\begin{array}{l}\text { fRoots } \\
\text { Songlines Magazine }\end{array}$ & -- & -- \\
\hline Online magazine & Innocent words & Buzzine & -- \\
\hline Music blog & -- & -- & Lucid Culture \\
\hline $\begin{array}{l}\text { Music promotion } \\
\text { and review website }\end{array}$ & -- & $\begin{array}{l}\text { rockpaperscissors.biz } \\
\text { bbc.co.uk }\end{array}$ & -- \\
\hline $\begin{array}{l}\text { Popular culture and } \\
\text { music content } \\
\text { website }\end{array}$ & $\begin{array}{l}\text { last.fm } \\
\text { Rob Adams Journalist }\end{array}$ & $\begin{array}{l}\text { algigs.co.uk } \\
\text { amazon.co.uk } \\
\text { UK Vibe.org }\end{array}$ & -- \\
\hline
\end{tabular}

Table 1: Research material sources and text types.

This media text data were analysed via close reading, concentrating on the aspects that construct the narratives of origin and professionalism. All the material used was chosen because of its variance and wide scope in terms of the forum, and place and time of publication. The timeline of the material covers Fowlis's ongoing solo career.

Julie Fowlis has been an active folk music artist since the early 2000s, starting her solo career in 2005, and has found a niche in the folk music business as a Scottish Gaelic language singer. Although she is not the only or the first artist of her kind, she has earned numerous accolades from music awards to cultural ambassadorships, and has a side career as radio and TV presenter. Therefore she is certainly one of the most prominent folk singers of her generation not only in Scotland and Great Britain but also in the United States and Europe. Immersed in Scottish Gaelic traditional singing from an early age at school and home, she has studied both classical and traditional music, and has a BA in applied music and an MA in material culture and environment (Anon. 2017; Anon. 2008; Adams 2012). 
Although Fowlis could more specifically be classified as a traditional singer and musician, in this article I call her folk singer and musician. The research material tends not to distinguish between folk and traditional music, or uses the terms interchangeably, with 'folk singer' taking precedence over 'traditional singer', but 'traditional music' and 'traditional song' taking precedence over 'folk music' and 'folk song'. Thus, for the sake of clarity, here I refer to Fowlis as a folk singer and her music as folk music.

In what follows I will first discuss the concept of authenticity, connect it to the concepts of cultural memory and premediation, and then examine the two narratives constituting Fowlis's authenticity in the media.

\section{Authenticity of a folk singer}

Authenticity as a concept is problematic as it eludes exact categorization and depends on the time, place and situation to which it is applied. Bendix defines authenticity 'as a quality of experience' (1997: 13), thus associating authenticity with emotions and as a reactional phenomenon. Authenticity is therefore an active concept, something that is looked for and bestowed upon phenomena. This also corresponds to Allan Moore's (2002: 210) statement of authenticity as being 'ascribed, not inscribed' to a performance. Thus, authenticity is applied from the outside by those who observe, say, a folk singer. Moore (2002: 210) also claims that the authenticity of an artist depends on who is observing and experiencing the artist's persona and performance.

Connection to a specific place is central to the authenticity of female folk singers. The origin narratives defining their national and ethnic identities highlight the need for belonging to a nation, social group or community that according to Vincent $\mathrm{J}$. Cheng is 
caused by the globalization of the postmodern world, pushing us to 'define a unique and authentic national character and identity, one that is distinct from all others' (2004: 31$)$. To belong is to represent, and as folk music as a genre is conventionally often understood as an extension of a particular nation or ethnic group, the performers of such music also represent the nationality, ethnicity or community connected to it (Gelbart 2007: 12; McKerrell 2016: 53). Further, as Steven Redhead and John Street argue, people define themselves in terms of a collectivity that has an associated culture, and this is mediated through music (1989: 178). As such, the authenticity of a musician is based on her 'right to speak for a community or people' and thus represent her audience (Redhead and Street 1989: 178).

Therefore, folk singer authenticity emerges in the close connection of the singer and her audience. One of Hans Weisethaunet and Ulf Lindberg's six directions of authenticity, folkloric authenticity, defines this process, whereby a performance represents a social community of some kind, be it cultural, national or joined together by a common experience (2010: 470-71, 478). Similarly, Keir Keightley defines this as a tendency to Romantic authenticity, with which the sense of community and connection to tradition are also central (2001: 135-37). The social community, and the influences of time and place define the authenticity of a female folk singer. When discussing the origins of the authenticity concept, Charles Lindholm (2008: 5) points out that

Tribes living in isolation (or even peasants living in the countryside) were imagined and portrayed as representative of coherent and pristine rural cultural traditions, integrated with nature, unashamed, communal, loving and close to the paradisiacal Garden of Eden. They were authentic in the double sense of being pure and original 
and of being without falsity. At the same time they were regarded as being in contact with the mysterious and primordial spiritual forces no longer perceptible to modern humanity.

Even though this statement refers to encounters between different cultures in the early modern time, it connects with the construction of authenticity in folk singer media presentations. The communality, the assumed purity of a culture and connections to traditions that folk singers demonstrate - which can be understood in this context as 'the mysterious and primordial forces' to which Lindholm refers above - all build an idealized representation of both the folk singer and the community that she represents. The authenticity ascribed on the artist is always a construct, a collection of features that meet the requirements of authenticity for a given audience, time and place. For the artist to be able to 'speak for a community' then means that the criteria for authenticity are fluid, changing and cannot be based on an established entity of 'people' (Redhead and Street 1989: 183).

Although in this article the narratives of origins and professionalism are examined separately, they overlap and influence each other. The connection to a place implies a connection to the traditions of that place, and thus the authenticity of a folk singer entails traditionalism in their work. This approach to performance and music is defined by Moore in his discussion of authenticity having three dimensions, first-person, second-person and thirdperson authenticity (2002), and by Keightley's Romantic authenticity (2001: 136-37). Thirdperson authenticity concerns the performer's ability to represent the ideas 'embedded within a tradition of performance' (Moore 2002: 218), whereas Romantic authenticity highlights the artist's connection with tradition, sense of community, her personal journey with the music, 
directness and naturalness of expression (Keightley 2001: 136). Therefore, the connection to tradition in the narratives of origins and professionalism constructing authenticity does not mean only such traditions that have to do with specific national, ethnic or local cultures, but also the traditions connected to the genre of music and the perception of the artists within its sphere.

Authenticity constructed by musical professionalism centres around that connection to tradition, but it also has to do with the sincerity of the artist's performance. Both Moore, with his definition of first person authenticity (2002: 214), and Keightley discussing Romantic authenticity (2001: 136) emphasize the importance of the authenticity of expression in musical performance. Within the genre of folk music this means, first, the natural, direct and 'unmodified' sound of the artist's voice and her performance, and second, the arrangement and performance of her music in a way acceptable to the genre norms of folk music.

Such authenticity of expression and sound is further enforced by the evidence of the artist's self-expression through her music, her talents and abilities and, perhaps most importantly, personal connection to the music that she is performing. According to Weisethaunet and Lindberg, the artist's individual expression, talent and personality are the defining features of authenticity as self-expression (2010: 472). For the artist be able to express herself through her music she needs to establish a personal connection to the music that she is performing and be true to her artistic integrity. This corresponds to what Keightley calls Modernist authenticity, second of his two tendencies of authenticity in popular music, and a part-opposite, part parallel to Romantic authenticity (2001: 135-37). 
Interpreting the above features of authenticity in an artist and her performance requires an individual's experience of the artist and her performance, but also the collective experience of a social group or a community of similar phenomena. Here, the active, creative processes of cultural remembering (Keightley and Pickering 2012: 6-7) and premediation connect to the process of authentication as discussed above. Astrid Erll explains cultural memory and remembering as having an individual and collective level, respectively, 'the socially and culturally formed individual memory' and 'the symbols, media, social institutions, and practices which are used to construct, maintain and represent versions of a shared past' (Erll 2011: 97-98). These levels interact and influence each other in the active process of remembering. I agree with Keightley and Pickering and also Erll in viewing the memory-making process as fundamentally creative and active. As such it makes possible to approach the concept of authenticity in this way, meaning that individual remembering takes place as part of a sociocultural environment (Erll 2011: 99), and at the same time, collectively negotiated memories exist of authenticated phenomena to which a new phenomenon is compared and evaluated as authentic or not authentic. These memories are based on 'a symbolic order, media and institutions' (Erll 2011: 99) through which individuals make sense of their experiences and interpret the past. Therefore, here the concept of premediation (Erll 2009 ) is essential. According to Erll, "premediation is a cultural practice of experiencing and remembering: the use of existent patterns and paradigms to transform contingent events into meaningful images and narratives' (2009: 114). This means that media that already exist memories, mythology and stereotypes - are used as templates for making sense and interpreting new experiences (Erll 2009: 111). The authenticity of a folk music artist thus 
emerges in close connection to their perceived identities as artists, to who they are and whether or not they appear credible in performing that identity.

\section{Construction of authenticity in the media representation of Julie Fowlis}

The descriptions of Fowlis's origins and her professionalism are the two main narratives that construct her as an authentic folk singer in the media. Irrespective of the type of the text or the publication channel, the same narratives appear in all, and these two narratives are analysed and discussed in the following chapters.

\section{A girl from a small island}

An identity connected to a specific place is central to the authenticity of a folk singer. Fowlis's place of origin, one of the three strands of her origin narratives (see Karjalainen 2017), is presented in the media as mythical and nostalgic, creating an imagined place with a specific culture and people that bear resemblance to their real counterparts but are nevertheless idealized and reconstructed (Karjalainen 2017: 5-7). This manifests in media texts for example via the parallels drawn in the media text data between the actual existing area of the Highlands and Islands where Fowlis is from, and 'an other world' (Radcliffe in Adams 2012: n.pag.) or 'a distant land' (Long 2007: n.pag.). Thus, the texts produce a misty storybook reconstruction of Scotland, a much-applied conceptualization dating back to the eighteenth and nineteenth centuries when the imagery and tropes for 'Scotland' as a nation emerged from the literary works of the time (McKerrell 2016: 98-100). Fowlis is linked to this mythical place and its specific culture in the media, and thus represents that reconstructed community. 
Such premediation of existing memories, media and imagery constructs authenticity, thus reinforcing the folkloristic connotations of Fowlis as an artist (Erll 2009: 111-14; Boyes 2010: 3, 22; Weisethaunet and Lindberg 2010: 470-71; Redhead and Street 1989: 177-78). As the English Folk Revivalists in the early twentieth century constructed the image of 'Merrie England' on idealized imagery of rural life free of any modern (at the time) social and political complications (Boyes 2010: 70-71), similarly, through her origin narratives, Fowlis's authenticity is constructed on the ideals of an early modern way of life:

1. Nestling in the heart of the wild and windswept Outer Hebrides is the island of North Uist, population about 1,200 . It's the home of folk singer Julie Fowlis, bearer of a voice as clear and pure as the blue Atlantic waters that lap its shores. (Cosyns 2008)

2. Raised in the Gaelic community of North Uist, Outer Hebrides, Scotland, Fowlis was ensconced in the musical tradition of her homeland. Fowlis embraced the long-established singing and dancing at an early age thanks to her family's background. (Michael 2009)

3. Julie Fowlis's music is at once strikingly youthful and timeless. Singing primarily in Scottish Gaelic (a language which only about $1 \%$ of the Scottish population can speak), her voice brings both her language and culture dancing to life with an almost unearthly presence. (Schaeffer 2009) 
As examples (1-3) above illustrate, the fabled region of Scottish Highlands where Fowlis originates, her native language in which she performs and the steadfast links she holds with tradition render her pure and original. As an added bonus, Fowlis is from a small rural island community in the Highlands, implying a connection with nature and a communal spirit, which are fertile ground for stories and songs, but also reflect the ever-present longing for a lost place or time, and experience of nostalgia. The 'mysterious and primordial spiritual forces' (Lindholm 2008: 5) are manifested in the stereotypical connotations of Scottishness and folk music that are connected to Julie Fowlis.

Fowlis is Scottish and openly owns up to her nationality, cultural and ethnic roots, and performs folk music, a genre with a close and often problematic relationship with national pride, culture and appreciation of the homeland (McKerrell 2016: 53). Therefore, the connotations attached to Scotland, Scottish culture and Scottishness in the public consciousness and preserved in the processes of cultural remembering (see Erll 2011: 98-99, $113,130)$ are invariably also attached to her and her music through premediation. Fowlis, her music and performance, and herself as a person, are repeatedly referred to as 'mystical', ‘beguiling', ‘charming', ‘elfin' and ‘otherworldly' (Irwin 2009; Haafke 2011; Gantz 2008; Adams 2012; Denselow 2014; Hopper 2008; Last.fm n.d.; Long 2007). Her representation emulates that of Scotland as a country in cultural memory, and stereotypical imagery attached to descriptions of Scottishness, such as the examples above, is used in describing her and her music. These tropes can be traced back to Sir Walter Scott's fiction writing and cultural mythologizing of Scotland with its unchanging hills, proud people and ancient traditions (McKerrell 2016: 63), and to concepts of tartanry and kailyardism (McKerrell 2016: 76, 99; 
West 2012: 161), through which Scotland is reduced to tartans, whisky, bagpipes and the country's supposedly magical and romanticized past.

Together with the qualities attached to the sound of her voice and her signature style, Scottish Gaelic as Fowlis's native performance language acts as 'sound'. In the media text data, Gaelic is described as having 'curious sounds and unusual structures', and understanding the lyrics is not necessary for the audience as the listener can 'rest simply on the sound' (Long 2007: n.pag.). This ununderstandable, mythical and exoticized quality of Fowlis's music results in her songs - and herself - being described as 'otherworldly' and originating from a 'distant land' (Long 2007: n.pag.). The nature of her music is further compared to 'Highland mist' (Long 2007), able to 'transpose [the listener] to the highlands [sic]' (Stenhouse 2009: n.pag.), thus linking it with the stereotypical images of Scotland and Scottish culture.

Fowlis's status as a native Gaelic speaker is an important constituent of her authenticity. Scottish Gaelic is the language of her family; it is the first language of her mother and she herself speaks it to her own children (Michael 2009; Nystrom 2009). In the media text data Fowlis is considered an authentic speaker of Scottish Gaelic also because of her birthplace North Uist, an island in the Outer Hebrides off the west coast of Scotland, and one of the few places where Scottish Gaelic is still an everyday language (Michael 2009; Gilbert 2008; Moss 2009; Terhune 2013). Even though she has not lived there since childhood, the detail is important for her media presentation and mentioned repeatedly. Fowlis represents Scotland, the modern Gaelic speaker and the revival of folk culture and music in that language. The media texts depict her as the 'Poster Gael' (Frost 2014) and as the 'Scottish singer [bringing] Gaelic tradition into the pop world' (Hopper 2008: n.pag.). Thus, she represents the ideas that are embedded within a tradition of performance (Moore 
2002: 218), in this case the performance of a folk singer, and more specifically a Gaelic language folk singer.

Although Julie Fowlis is not the only or the first folk singer to perform in Scottish Gaelic or other minority language in the Great Britain folk music scene, her success in bringing 'Gaelic song to a following that is far wider than the language's 60,000 speakers in Scotland' (Denselow 2008: n.pag.) has ensured the media attention she has enjoyed since her first solo album in 2005. Fowlis is also said to have 'changed the face of Scottish music by proving that an artist singing almost exclusively in Gaelic can become an international success' (Denselow 2014: n.pag.). Considering that Scottish Gaelic language in Scotland has been in steep decline since the mid-eighteenth century, and has been actively run down by the government and official institutions, and did not receive an official minority language status until 2005 (Anon. 2005a; Anon. 2005b), Fowlis's success as a Scottish Gaelic language folk singer is as timely as it is a political phenomenon. Fowlis's performance language factors in the active processes of remembering and premediation, and thus her artist persona and performance are interpreted not only in terms of folk music artists and performances or Scottish traditional music artists and performances, but also in terms of minority language artists and performances.

Fowlis is respectful about her cultural and musical heritage, including promoting awareness on Scottish Gaelic. This appreciation of tradition and heritage that Fowlis demonstrates especially in the interviews included in the media text data is the third strand of her origin narratives, the 'tradition' (Karjalainen 2017: 9). The interview questions most commonly asked of her centre around her musical background, singing in Gaelic, the songs and their origins, Gaelic language and culture, her other projects besides making music, the awards that she has received, her albums, and her family and life as a musician. Her answers 
reveal that she has great passion for the music she performs and feels responsible for doing justice to the songs that have been entrusted in her care:

4. So my challenge is to bring these songs to an audience in such a way that we're making them accessible while being true to the tradition. (Fowlis in Adams 2012)

5. I want to be as true to the songs as I can whilst being true to myself as a musician. $[\ldots]$ if I present the songs in this way it shows that I have real respect and affection to them. (Fowlis in Chipping 2014)

6. It feels like a weight on my shoulders, in a good way, knowing that each time I go to a place and perform there will be people who have never heard it before. With that comes a responsibility to do right by it by presenting it in the right way. (Fowlis in Hindmarch 2008)

Such a serious connection to the songs implies a connection to her place of origin and the members of her immediate community. She finds her material in the traditional way 'passed onto [her] by tradition-bearers - people [she knows], family members, friends of the family' (Leadbetter 2012: n.pag.), largely by word of mouth from 'older singers and musicians in the community, teachers, [her] peers' (Cosyns 2008: n.pag.). Her musical activities, from sourcing her songs, arranging and performing them in her signature style, to the sound of her voice and her abilities to affect the listeners despite the language barrier, are highlighted throughout the media text data. These answers provide insight into how she perceives her 
music and her personal connection to it. Therefore interviews on their part very clearly steer the construction of Fowlis's authenticity as a folk singer on her origins and her professionalism.

Fowlis's connection to tradition and her methods for finding her music follow the traditions of the folk music field: that her approach to music is accounted in detail in the research material reflects the audience's amazement for finding out that this kind of traditional approach to music is still possible, people still remember songs by heart and that there are others who want to learn them just by listening them singing those songs. This is well illustrated in the following example:

7. That Fowlis, the elfin beauty with a voice alternating between piper's staccatos and flautist's glissandos, should spend her days in a fire-lit croft house, learning songs in an all-but-departed language, is a testament to her passion for the music. (Hopper 2008)

The authenticity-constructing facet of tradition is visible in the way she gathers her song material: the 'fire-lit croft house', 'all-but-departed language' and 'her passion for the music' emphasize the unusualness of such a way of approaching music and in their part validate Fowlis's authenticity as a folk singer. Describing her as being an 'elfin beauty' attaches to her the typical mythical elements that are often used in connection to Scotland (McKerrell 2016: 64). Depicting her this way and not for example declaring her to be a classic beauty makes her more approachable, affable but slightly mystical, lending her an air of 
mischievousness. Her place of origin is thus referred to, as is the sound facet of her origins. Mentions of pipes and flutes, musical instruments typical for traditional music and her vocal abilities underline her connection to the genre traditions and also draw attention to her musical expertise. This excerpt assures that Julie Fowlis is an artist steeped in tradition, authentic to the core in her craft and harking back to the golden age of her people through her passion. Therefore it also reflects Romantic authenticity but it could also be interpreted as Modernist authenticity (Keightley 2001: 135-37) because from the perspective of contemporary audience, the strangeness of Fowlis's material and her performance make her appear innovative, and re-inventing the tradition.

Fowlis in the media is presented as an ambassador of her country and culture, '[giving] new life to Gaelic' and 'pleased to be a part of a Scottish revival' (Moss 2009: n.pag.). She 'finds resonance with the present with tunes from Scotland's past' (Gilbert 2008: n.pag.) and 'is proud to show of [her] roots' (Hindmarch 2008: n.pag.). As McKerrell also notes, the current trend in movies and on television is to have 'authentic traditional music and musicians [...] representing Scotland in sound' (2016: 120), which links directly to Fowlis, her music representing Scotland in traditional music programmes, radio broadcasts and even in a Disney film (Brave (Andrews and Chapman 2012)). Although in Julie Fowlis's case the weight of her place of origin, performance language and the heritage and traditions of her native country define her authenticity as a folk singer, she represents an authentic Scottish Gaelic folk singer to an audience extending outside the sphere of her native country and aficionados of her musical genre. The very similar media presentations produced by the various journalists suggest that being categorized and identifying as folk singer results in a clearly typified presentation in the media that is deeply embedded in the process of cultural 
remembering. As Keightley and Pickering also state, such 'employment of cultural conventions of representation loosens the past experiences from the specific social situations of their production' (2012: 108). Here, this means that in the active and creative process of remembering the previous experiences and interpretations of what is an authentic folk singer are applied more widely than what they were in connection to a specific artist in the past. This authentication is the product of premediation in the process of remembering. Judging on the uniformity of the narratives of authenticity, Fowlis's audiences (the journalists included) have preconceptions and established ideas about what is a folk singer and what Scottish traditional music is or may be like, and such ideas are influencing the narratives constructing her authenticity and her media representation.

\section{An award-winning Gaelic singer}

Authenticity in the context of folk music has to do not only with the authenticity of the artists as folk musicians, but also with their authenticity as musicians, as folk music has been seen as a part-time, uncommercial and amateur or only semi-professional pursuit on which it is not possible to make a living (see Finnegan 1989: 16-18; Miller 2014 \& 2018: 72-74). Although the numerous professional folk music artists and bands in the British Isles with lifelong careers and success rather refute the last point, the presentation of folk singers in the media - especially in mainstream publications, for example large daily newspapers such as The Guardian and The Telegraph - signifies that a folk musician's musicianship has to be justified by listing and discussing their professional and other achievements related to their music-making.

Fowlis's professionalism is therefore another dimension of her authenticity as a folk

musician. Her musicianship, work ethic and dedication to the craft construct the narrative of 
her professionalism that - together with the origin narratives - constructs her authenticity as a folk singer. In the media text data her academic background and achievements are detailed, her awards are listed and her worldwide popularity is marvelled at (Michael 2009; Nystrom 2008; Adams 2012; Denselow 2008; Terhune 2013; Irwin 2011; Gilbert 2008; Moss 2009; Roberts 2009; Chipping 2014; Anon. 2012). The serendipitous way in which she entered the music business is recounted, quoting her own words of how '[she] just took the plunge and resigned from [her] job and started playing music full time' (Nystrom 2009: n.pag.). All this, connected to her documented passion for tradition, and her appreciation of her cultural history and heritage, builds her authenticity as a folk musician.

Folk singers such as Fowlis are depicted as acknowledging their roots and being aware of the continuum in their musical endeavours from the earlier times to the present, whether it is the folk revival period of the 1960s, the nineteenth-century rural societies' traditions or even an earlier period in the sphere of folk music. Presenting Fowlis as a professional artist links to these artistic origins through the descriptions of her musical processes. She is thus constructed not only as a sincere artist with a thorough understanding of the traditions that she feels she is entrusted with (Adams 2012; Roberts 2009), but also as an inventive musician whose originality and ability to give traditional material an individual twist without sacrificing its realness has secured her a niche in the folk music scene (Long 2007; Irwin 2011).

Fowlis is thus presented in the media in terms of both her geographic and artistic origins, highlighting rurality and traditionality, a life close to nature, artistry as a personal self-discovery and fulfilment, which in Keightley's terms reflect Romantic authenticity (2001: 135-37). However, according to him, most artists cannot be categorized cleanly to 
represent only one or the other of his two tendencies of authenticity, which mostly overlap and form hybrids. This is also evident in Fowlis's case and I argue that 'the belief that a true artist must keep moving forward, constantly re-inventing him or herself' (Keightley 2001: 136), albeit attributed to Modernist authenticity, is also applicable when discussing folk singers such as Fowlis. Her musical reinvention or forward-moving may not be as radical as for example that of rock or indie musicians, but it is visible in her professionalism, in her staying true to their chosen genre and the traditions, and still finding new things and new ways to work with the tradition, thus proving its vitality and resilience.

Also Fowlis has been authenticated in the media as a folk singer via the common strategy of comparison in popular music journalism and popular music scene, which according to Anttonen has to do with 'mentioning other, already established artists, or alleging an association with them, is a way to construct authenticity' (2015: 94). Perhaps the most cited description of her in the media, by a BBC Radio 2 presenter Mark Radcliffe, likens Fowlis and her music to Kate Bush and Björk (Adams 2012; Last.fm n.d.), thus constructing her credibility as a musician in the mainstream media. Although Fowlis's music represents a different genre of music and is nothing like that of Bush or Björk, such a comparison places her in the company of other female artists boldly creating unconventional music. A similar authenticity-constructing parallel has also been drawn within the genre of folk music, comparing Fowlis to Kate Rusby, a well-established English language folk singer who at the time of such comparisons already had a ten-year career under her belt and eight published albums. Therefore, describing Fowlis at the early stages of her career as a solo folk singer as 'Kate Rusby singing in Gaelic' (Magnussen 2007 in Anon. 2007) or saying that '[i]n some ways she's like a Scottish Kate Rusby' (Baker 2007 in Anon. 2007) placed her in the field of 
folk music and provided building blocks for her media presentation as a legitimate folk music artist.

Richard Peterson discusses this phenomenon, 'authenticity through group membership' (2005: 1087), whereby the artists themselves claim such an association, but in the case of Fowlis, journalists writing about her make such comparisons to construct her authenticity in the media. As folk authenticity and its defining aspects are in many ways the basis of rock authenticity (Keightley 2001: 120-30), the narrative of professionalism that constructs Fowlis's authenticity as a folk singer is similar to other female artists independent of the genre of music. Thus, comparisons of Fowlis to established female singer-songwriters of both folk genre and the more mainstream music genres not only establish her as a credible artist but also manifest the existence of such parallels in authenticity construction.

The duality of authenticity versus inauthenticity is also present in the makeup of folk singer media representations, as the realness, and the authenticity of the artists is always underlined, either by stating it bluntly or by implying it through the artists' nationalities, ethnicities or professional merits. Bendix (1997: 9) states that 'the notion of authenticity implies the existence of its opposite, the fake, and this dichotomous construct is at the heart of what makes authenticity problematic'. As the case of Julie Fowlis shows, a credible, authentic folk singer needs to have a personal connection to the music and exhibit an understanding and appreciation of the traditions that she is upholding and using for her artistic endeavours. When convincing narratives of origins and professionalism deem the singers authentic, they are taken seriously within the genre. Allan Moore discusses the concept of authenticity as primality in which 'an expression is perceived to be authentic if it can be traced to an initiatory instance' (2002: 213). This is a particularly fitting 
characterization of the genre of folk music and folk singers since their musical processes and media representations are built on the assumption that they follow the tradition and that their work can be linked to the so-called original version (although no such version actually exists), thus validating their efforts (Moore 2002: 215).

A musician's work ethic authenticates not only folk singers but also musicians of all the genres of music. The rock authenticity discourses often describe music-making and a musician's work methods as destructive and in some way bad for the artist, and as something they cannot do in any other way (Anttonen 2015: 89). Thus, this image of a self-destructive suffering artist makes them authentic. The contemporary female folk singers, Fowlis included, differ from this considerably, projecting a wholesome, thoroughly nice and almost innocent image, where family is at the centre, and no drugs or alcohol are abused, or even mentioned (Adams 2012; Michael 2009; Nystrom 2009; Terhune 2013). Although Fowlis works hard, makes albums, tours and performs, she does it in a way that is presented as normal, everyday and glamourless.

A feature of the professionalism narrative constructing folk singer authenticity is that there are no rags to riches stories with folk singers because it is assumed that none of them takes up folk music to make a fortune; the most important thing is the dedication for the craft, and not selling out, which reflects the ideals of rock authenticity (see Keightley 2001: 12832). In Fowlis's words

8. I have never set out to play music with an agenda - if folk like it, great, I am delighted - but I am not about to compromise what I do musically to please anyone. [...] If I had wanted to hit the mainstream I would have ditched Gaelic 
long ago, learned to lip-sync and developed a dance routine. (Fowlis in Anon. 2008)

According to the above example, Fowlis has not chosen to become a folk musician to become rich and famous; indeed, concert and album reviews repeatedly marvel at her popularity despite her being a Scottish Gaelic folk singer. By working hard, and doing what she considers important and reflecting her artistic integrity, she has nonetheless reached a worldwide audience and 'resign[ing] from [her] job to follow a dream' (Cosyns 2008: n.pag.) has resulted in a successful solo career. The serendipitous nature of Fowlis's success is further underlined by her own statements of how in retrospect she has realized 'how instrumental it [her upbringing] was in what I ended up doing in my life for a job' (Fowlis in Hindmarch 2008: n.pag.) and how she 'still can't quite believe I'm doing this. None of it was ever planned. It's all happened by accident. We're not trying to be anything we're not [...]' (Fowlis in Irwin 2008: n.pag.). This unplannedness of Fowlis's success solidifies her authenticity as a folk singer because it demonstrates the value of uncommercialism attached to folk and traditional music, and ensures that she is performing her music for the reasons acceptable for the canon of folk authenticity, not for money and fame but because of necessity dictated by genuine love and dedication for the tradition.

The process of premediation in remembering (Erll 2009, 2011) is also at work with the narrative of folk singer professionalism constructing her authenticity in the media. The artist's connection to music, the interpretation of tradition in a respectful way and descriptions of such features imply that both the artist and the audiences have a premediated idea about what is an authentic folk singer and how she performs and works. This narrative 
implies that the existence of past and the history of the genre and the past masters is recognized but it is understood that the contemporary artists such as Julie Fowlis are remaking the tradition, with respect to what has gone before but creating new on that basis. The constructions of Fowlis's authenticity as a folk singer reflect the ways in which she as an artist interprets her traditional material and makes it her own. In this narrative, therefore, premediation in the process of remembering factors in with discussing Fowlis's artistic origins, but also with what she is doing with her music now and how she is authenticated because of it.

\section{Conclusions}

The media texts studied in this article interpret Fowlis's music and public persona, and manifest the narratives of origins and professionalism constructing her authenticity. She is the 'Poster Gael' (Frost 2014), representing the new Gaelic speaker, but presented in terms of what can be termed early folk revivalist ideals - 'simplicity, purity, directness, unaffected beauty' (Boyes 2010: 71) - and stereotypical imagery connected to Scotland, which portray tradition as something stagnant, quaint and in need of preservation. On the other hand, she is also presented in terms of her professionalism and as a representative of a living and vibrant culture based on tradition, constantly remaking and reinterpreting it. These two narratives set Fowlis up as a representative of a community of people - whether it is her local community, the people of Scotland at large or the multicultural audience of her music - and conforming to the generalizations and stereotypical images of a particular musical genre, and particular nationality and ethnicity. However, the personal connection to the music, the professional pride and a sense of responsibility are at the centre of her media presentations, showing that 
superficial appearance and compliance to the norms of the genre of music are not enough, but that the deeds of an authentic artist speak for her. Fowlis's own agency in constructing the authenticity of her artist persona in the media is visible in the interviews that she has given, bringing her closer to the audience and fans, demonstrating that she is just 'a girl from

a small island' (Hindmarch 2008: n.pag.), but also indicating her professionalism and, through it, her authenticity as an active, socially conscious folk singer, constructing her as 'an award-winning Gaelic singer' (Michael 2009: n.pag.).

These processes of authentication of Fowlis as a folk singer in the media are products of cultural remembering and the process of premediation within it (see Erll 2011, 2009). Although remembering inherently implies looking backwards, and recollecting an earlier experience, I argue that as a process it has equally to do with interpreting the present and the future and making sense of an experience on the basis of what is happening now, rather than simply on the basis of what has happened in the past. Therefore, the construction of a female folk singer's media representation and ascribing authenticity on her have as much to do with appreciating the past and tradition as something romantic, mythical and nostalgic, as they have with interpreting and understanding the tradition and its exponents, and the links they forge with the past, present and future.

\section{References}

Adams, R. (2012), 'Julie Fowlis - on Brave, Gaelic, flowers and couture', http://www.robadamsjournalist.com/index.asp?pageid=538283. Accessed 1 April 2015. 
(2014), 'Julie Fowlis shifts focus from Brave to Bannockburn', Herald Scotland, 28

June,

http://www.heraldscotland.com/arts_ents/13167608.Julie_Fowlis_shifts_focus_from_Brave _to_Bannockburn/. Accessed 3 August 2017.

Andrews, M. and Chapman, B. (2012), Brave, USA: Walt Disney Pictures \& Pixar Animation Studios.

Anon. (2005a), 'Gaelic Language (Scotland) Act 2005', http://www.legislation.gov.uk/asp/2005/7/contents. Accessed 17 April 2018.

(2005b), 'Historic day for Gaelic', 21 April, http://www.gov.scot/News/Releases/2005/04/21162614. Accessed 17 April 2018. (2007), ‘Julie Fowlis: Cuilidh', http://www.amazon.co.uk/CuilidhJulieFowlis/dp/B000NA2PRS/ref=cm_cr_pr_product_top. Accessed 1 April 2015. 
(2008), ‘Sixteen questions for Julie Fowlis’, Lucid Culture. Jazz, Classical Music and the Arts, New York City, https://lucidculture.wordpress.com/2008/09/16/sixteen-questionsfor-julie-fowlis/. Accessed 3 August 2015.

(2012), 'Gaelic singer nominated for Oscar', Herald Scotland, 27 December, http://www.heraldscotland.com/news/13086234.Gaelic_singer_nominated_for_Oscar/. Accessed 3 August 2017.

(2017), 'Julie Fowlis - The official home page', http://www.juliefowlis.com/. Accessed 1 April 2015.

Anttonen, S. (2015), “"The lie becomes the truth". Constructions of authenticity in Rolling Stone's cover stories of Lady Gaga', in M. Kytö and S. Rantanen (eds), Etnomusikologian vuosikirja 2015, vol. 27, Helsinki: Suomen Etnomusikologinen Seura, pp. 82-111, http://julkaisut.etnomusikologia.fi/EVK/EVK_Vol_27_2015.pdf.

Bendix, R. (1997), In Search of Authenticity: The Formation of Folklore Studies, Madison: University of Wisconsin Press, https://ebookcentral-proquestcom.proxy.uwasa.fi/lib/tritonia-ebooks/detail.action?docID $=3444883$. 
Boyes, G. (2010), The Imagined Village. Culture, Ideology and the English Folk Revival, Leeds: No Masters Co-operative Limited.

Cheng, Vincent. J. (2004), Inauthentic: The Anxiety over Culture and Identity, New Brunswick: Rutgers University Press, https://ebookcentral-proquestcom.proxy.uwasa.fi/lib/tritonia-ebooks/detail.action?docID=3032096.

Chipping, T. (2014), 'Uneasy Listening', fRoots, no. 370, April 2014, pp. 38-39.

Cosyns, S. (2008), 'Mesmerising with every word', The Sun, 4 April, http://archive.rockpaperscissors.biz/index.cfm/fuseaction/current.articles_detail/project_id/ 380/article_id/9506.cfm. Accessed 3 August 2015.

Denselow, R. (2008), 'Going back to her roots', The Guardian, 1 August, http://www.theguardian.com/music/2008/aug/01/folk.gaelic. Accessed 14 November 2014.

(2014), 'Julie Fowlis review—-"Scottish Gaelic songs with clear, gently thrilling vocals",, The Guardian, 11 April, http://www.theguardian.com/music/2014/apr/11/juliefowlis-review. Accessed 14 November 2014. 
Erll, A. (2009), 'Remembering across time, space, and cultures: Premediation, remediation, and the "Indian Mutiny", in A. Erll and A. Rigney (eds), Mediation, Remediation, and the Dynamics of Cultural Memory, De Gruyter, pp. 109-38, https://ebookcentral-proquestcom.proxy.uwasa.fi/lib/tritoniaebooks/detail.action?docID=453835.

(2011), Memory in Culture, Basingstoke: Palgrave Macmillan.

Finnegan, R. (1989), The Hidden Musicians: Music-Making in an English Town, Middletown: Wesleyan University Press.

Frost, J. (2014), ‘Gaelic stories’, Songlines Magazine, no. 99, April/May, pp. 32-37.

Gantz, J. (2008), 'Julie Fowlis. Cuilidh', The Boston Phoenix, 16 September, http://archive.rockpaperscissors.biz/index.cfm/fuseaction/current.articles_detail/project_id/ 380/article_id/9920.cfm. Accessed 3 August 2015.

Gelbart, M. (2007), The Invention of 'Folk Music' and 'Art Music'. Emerging Categories from Ossian to Wagner, Cambridge: Cambridge University Press. 
Gilbert, A. (2008), 'With tunes from Scotland's past, she finds a resonance with the present', The Boston Globe, 23 September, http://archive.rockpaperscissors.biz/index.cfm/fuseaction/current.articles_detail/project_id/ 380/article_id/9971.cfm. Accessed 3 August 2015.

Haafke, U. (2011), 'Julie Fowlis - Personal view on Scottish folk music', http://www.schottlandberater.de/artikel/julie-fowlis-personal-view-on-scottish-folkmusic.html. Accessed 28 October 2013.

Hindmarch, T. (2008), 'Girl from small island proud to show off roots', The Sentinel, 31 October, http://www.stokesentinel.co.uk/Girl-small-island-proud-roots/story-12585904detail/story.html. Accessed 3 August 2015.

Hopper, J. (2008), 'Scottish singer Julie Fowlis brings Gaelic tradition into the pop world', $\begin{array}{llll}\text { Pittsburgh } \quad \text { City } & \text { Paper, } & 25 & \text { September, }\end{array}$ http://archive.rockpaperscissors.biz/index.cfm/fuseaction/current.articles_detail/project_id/ 380/article_id/9981.cfm. Accessed 14 November 2014. 
Irwin, C. (2008), 'Gael force twins', Penguin Eggs, no. 40, Winter, http://archive.rockpaperscissors.biz/index.cfm/fuseaction/current.articles_detail/proje ct_id/380/article_id/10660.cfm. Accessed 3 August 2015.

(2009), 'Julie Fowlis: Uam, CD review', The Telegraph, 30 October, http://www.telegraph.co.uk/culture/6468636/Julie-Fowlis-Uam-CD-review.html. Accessed 28 October 2013.

(2011), 'Julie Fowlis live at Perthsire Amber review', http://www.bbc.co.uk/music/reviews/c5b6. Accessed 13 September 2014

Last.fm (n.d.), 'Julie Fowlis artist page', http://www.last.fm/music/Julie+Fowlis. Accessed 1 April 2015.

Karjalainen, Noora (2017), 'Place, sound, and tradition: Origin narratives constructing nostalgia in the media representations of female folk singers'. Journal of Popular Music Studies 29:3, 1-12. http://onlinelibrary.wiley.com/doi/10.1111/jpms.12219/epdf.

Keightley, K. (2001), 'Reconsidering rock', in S. Frith, W. Straw and J. Street (eds), The Cambridge Companion to Pop and Rock, Street, Cambridge: Cambridge University Press, pp. 109-42. 
Keightley, E. and Pickering, M. (2012), The Mnemonic Imagination. Remembering as Creative Practice, Basingstoke: Palgrave Macmillan.

Leadbetter, R. (2012), 'The voice of brave', Herald Scotland, 22 July, http://www.heraldscotland.com/arts_ents/13066252.The_voice_of_Brave/. Accessed 3 August 2017.

Lindholm, C. (2008), Culture and Authenticity, Malden: Blackwell Publishing Limited.

Long, C. (2007), 'Julie Fowlis Cuilidh review', http://www.bbc.co.uk/music/reviews/bpzf. Accessed 13 September 2014.

McKerrell, S. (2016), Focus: Scottish Traditional Music, London: Routledge.

Michael, T. (2009), 'An award-winning Gaelic singer Julie Fowlis to perform at the Highdive in Champaign', Innocent Words 2009, http://archive.rockpaperscissors.biz/index.cfm/fuseaction/current.articles_detail/project_id/ 380/article_id/11007.cfm. Accessed 3 August 2015. 
Miller, Diana L. (2014), 'Sustainable amateurism: Music careers in folk and metal', http://www.csa-scs.ca/files/webapps/csapress/culture/2014/12/02/sustainable-amateurismmusic-careers-in-folk-and-metal/. Accessed 22 August 2016.

(2018), 'Sustainable and Unsustainable Semi-professionalism: Grassroots Music

Careers in Folk and Metal'. Popular Music and Society, 41:1, pp. 71-88.

http://dx.doi.org/10.1080/03007766.2016.1209901.

Moore, A. (2002), 'Authenticity as authentication', Popular Music, 21:2, pp. 209-23, https:/www.cambridge.org/core/services/aop-cambridgecore/content/view/S0261143002002131.

Moss, J. (2009), 'Scottish folk singer gives new life to Gaelic. Julie Fowlis is pleased to be part of a Scottish Gaelic revival', The Vancouver Sun, 19 February, http://archive.rockpaperscissors.biz/index.cfm/fuseaction/current.articles_detail/project_id/ 380/article_id/10934.cfm. Accessed 3 August 2015. 
Nystrom, A. (2009), 'Julie Fowlis to bring Gaelic songs to Northshore Performing Arts

Center, $\quad$ Bothell Reporter, $\quad 9 \quad$ February, http://archive.rockpaperscissors.biz/index.cfm/fuseaction/current.articles_detail/project_id/ 380/article_id/10936.cfm. Accessed 3 August 2015.

Peterson, Richard A. (2005), 'In search of authenticity', Journal of Management Studies, 42:5, pp. 1083-98.

Redhead, S. and Street, J. (1989), 'Have I the right? Legitimacy, authenticity and community in folk's politics', Popular Music, 8:2, pp. 177-84.

Roberts, E. (2009), 'Uam from me - Julie Fowlis album review', http://www.allgigs.co.uk/view/review/4369/Julie_Fowlis_Uam_From_Me_Album_Review .html. Accessed 14 November 2014.

Schaeffer, Ashley (2009), ‘JULIE FOWLIS ‘Cuilidh’ Special Edition’. Buzzine 15 October, https://web.archive.org/web/20100220101356/http://buzzine.com/2009/02/julie-fowlis/. Accessed 3 August 2015. 
Stenhouse, T. (2009), 'Julie Fowlis', UK Vibe, http://ukvibe.org/excursions/julie-fowlis/. Accessed 14 November 2014.

Terhune, V. (2013), 'Musician brings Gaelic to BlackRock: Whiskey tasting adds to festivities', Fairfax County Times, 23 October, http:/www.fairfaxtimes.com/article/20131023/ENTERTAINMENT/131029874\&template =fairfaxTimes. Accessed 20 October 2014.

Weisethaunet, H. and Lindberg, U. (2010), 'Authenticity revisited: The rock critic and the changing real', Popular Music and Society, 33:4, pp. 465-85.

West, G. (2012), Voicing Scotland. Folk, Culture, Nation, Edinburgh: Luath Press Limited.

\section{Contributor details}

Noora Karjalainen is a salaried Ph.D. candidate at the University of Jyväskylä, Finland. Her research focuses on the media representations of contemporary female folk singers, examining the narratives of origin, authenticity, performance and otherness emerging from the research material of album and concert reviews, articles and interviews written about the artists. These narratives have directed her research into memory and nostalgia studies, authenticity studies, gender studies and postcolonial studies. She has presented papers 
several times at both Finnish and international conferences, including the Finnish Music

Researcher's Symposium, International VAKKI Symposium, EUPOP Conference and ICTM

World Conference.

Contact:

E-mail: noora.p.karjalainen@jyu.fi

https://orcid.org/ 